
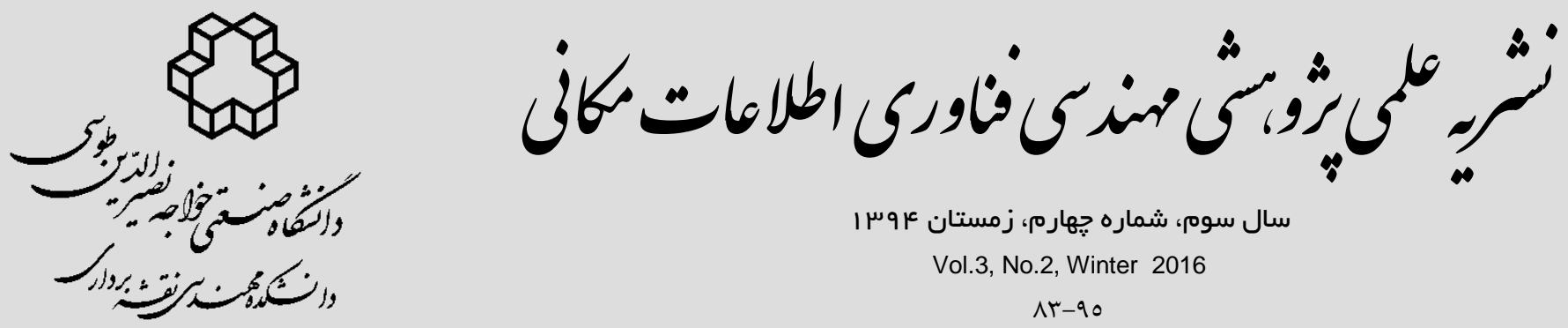

سال سوهم، شماره جِهارم)، زمستان ع وس

Vol.3, No.2, Winter 2016

$\wedge r-90$

الكوريتمى براى فشردهسازى خطوط سير مكانى با حفظ ماهيت معنايى

سميه عاقل شاهنشين '، سيمين سادات ميروهابى '، رحيم علىعباسيور "ro

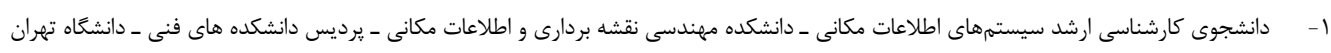

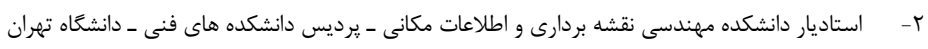

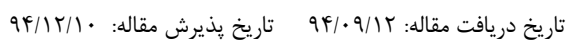

جكيده

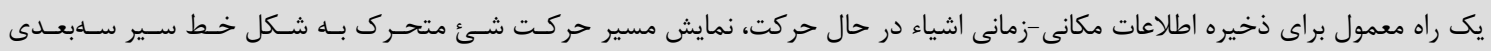

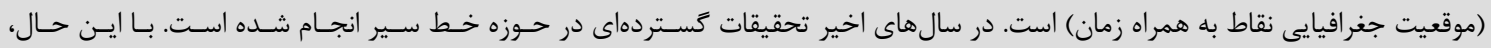

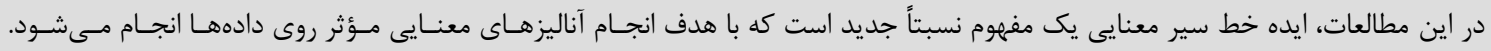

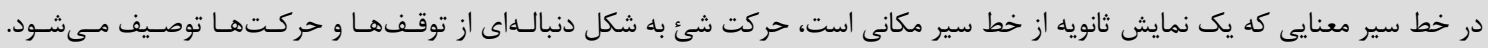

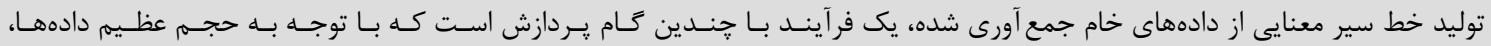

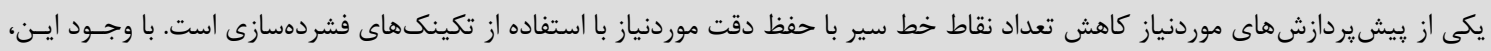

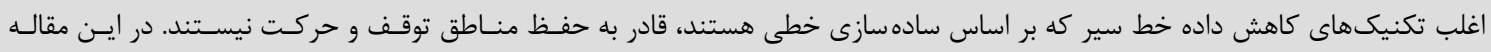

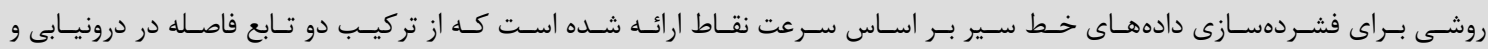

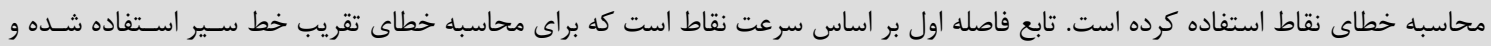

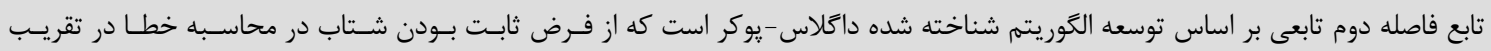

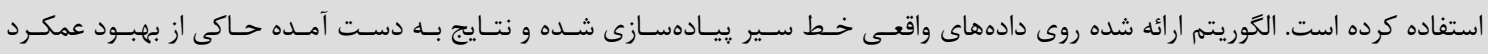

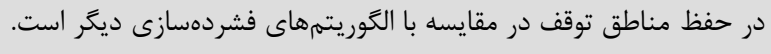

كليدوازهها: خط سير معنايى، فشردهازى، مدل توقف-حر كت،

نويسنده مكاتبه كننده: تهران-خيابان كاركر شمالى، بعد از تقاطع آل احمد، يرديس دانشكدهاى فنى دانشكاه تهران، دانشكده مهندسى نقشهبردارى و اطلاعات مكانى تلفن: توبره 
شئ متحرك براى انجام فعاليتهاى مهم و يا در

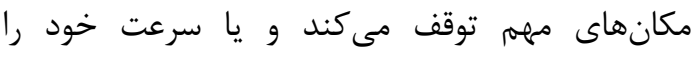

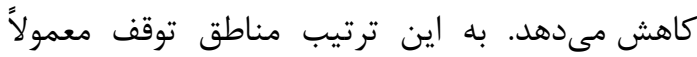
به صورت تراكم نقاط در مناطق توقف (به دليل توقف شئ متحرك و يا كاهش سرعت) و يا نبود سيكنال (به دليل ورود شئ متحرك به فضاى بسته) GPS

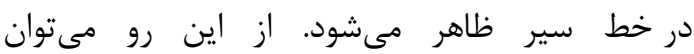

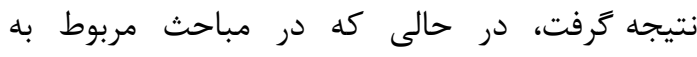
خطوط سير هندسى، مسير حركت شئ متحرك مبناى

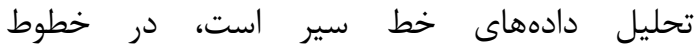
سير معنايى، علاوه بر مسير حركت شئ متحرك،

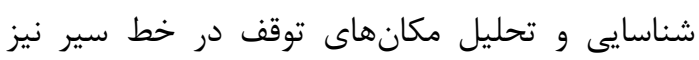
از الهميت ويزهاى برخوردار است. شكل 1 مثالى از خط سير هندسى و خط سير معناي آنسيى

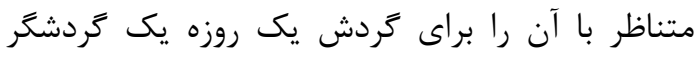

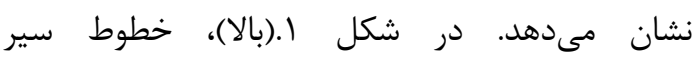

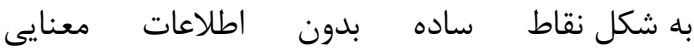
نشان داده شدهاند. در شكل ا.(يايين)، اطلاعات معنايى ندان

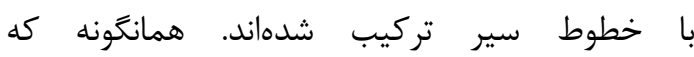
مشاهده مىشود، در خط سير معنايى، مكانهاى مهرم از

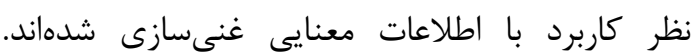

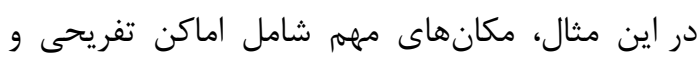
كر دشكَى و محل اقامت هستند.

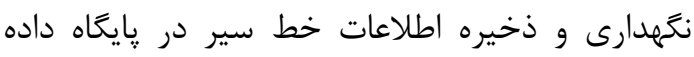

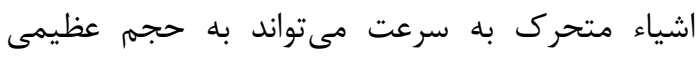

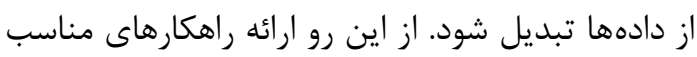
براى مديريت مؤثر اين حجم عظيم از دادهها ضرورى

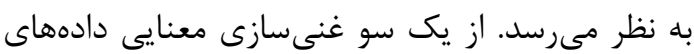

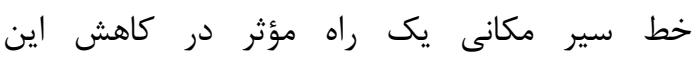

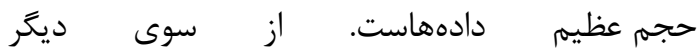
در يردازش دادهها كه با هدف آمادهسازى دادههاى

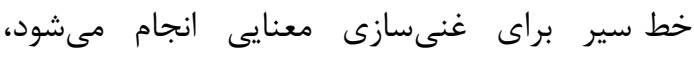

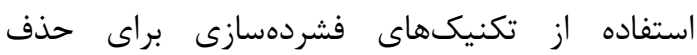
دادههاى اضافى مى تواند مورد استفاده قرار كيرد. با اين

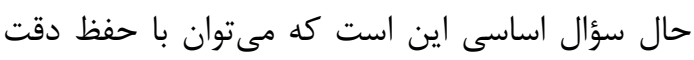

امروزه تعيين موقعيت توسط دستخاههاى سيار

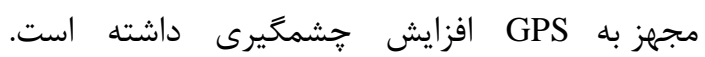

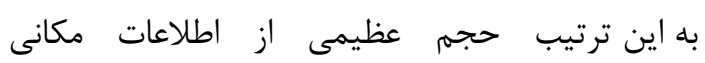
بلهور مداوم و روزانه توليد مىشود. تعيين موقعيت

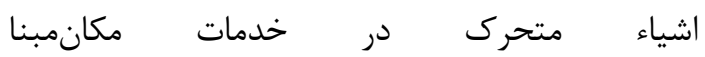

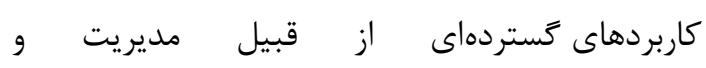

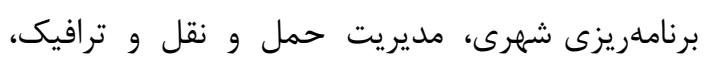

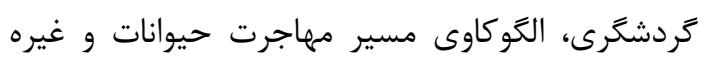

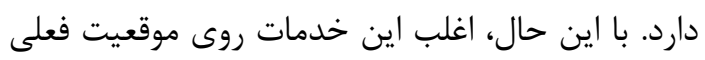

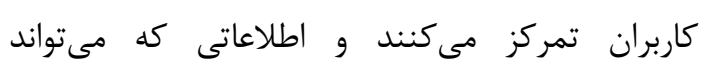

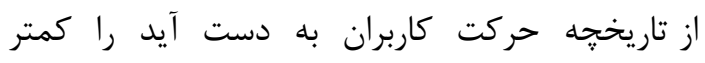

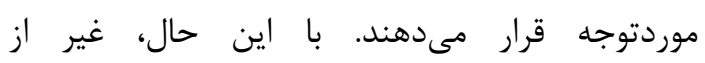

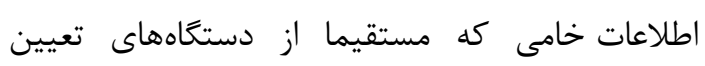

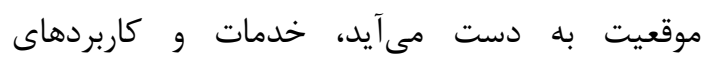

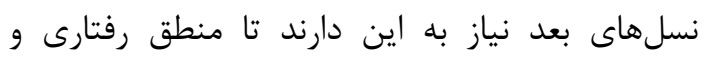

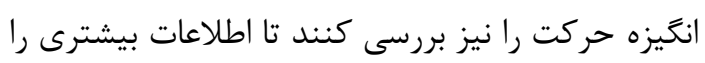

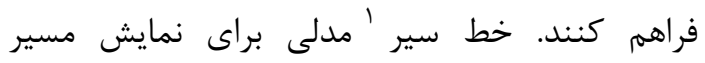

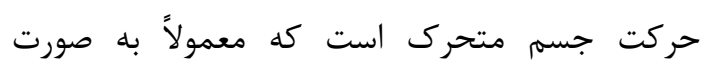

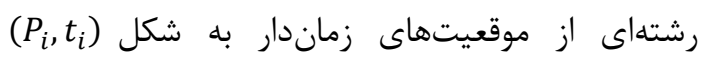

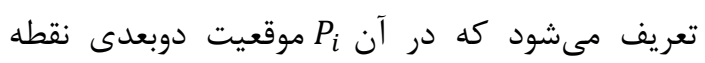
يعنى

است [1]

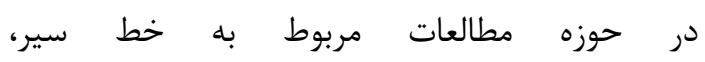

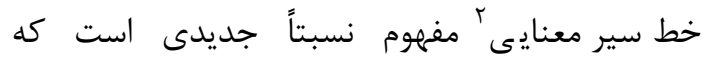

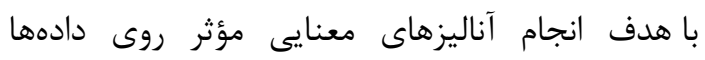

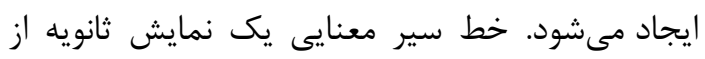

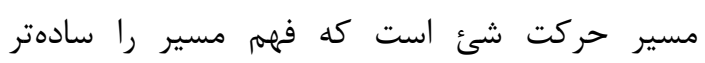

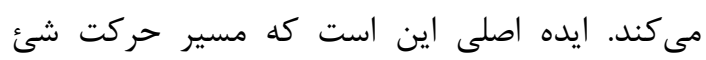

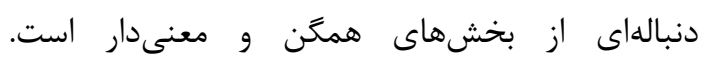

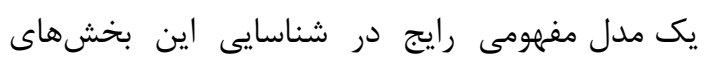

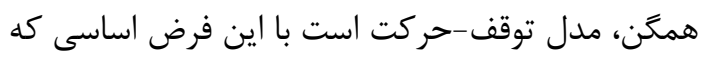

\footnotetext{
${ }^{1}$ Trajectory

${ }^{2}$ Semantic Trajectory
} 
قابل رِيشبينى هستند؛ در نتيجه بسيارى از موردنياز به حذف تعدادى از دادهها يرداخت. با توجه

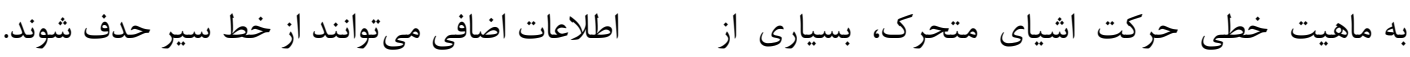
كاربردهاى مربوط به خدمات مكانمبنا داراى الكوهاى

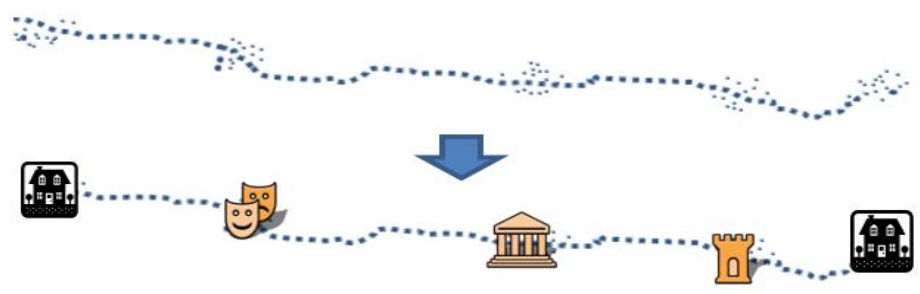

شكل ا: خط سير هندسى (بالا) كه معادل خط سير معنايى (پايين) است[ץ]

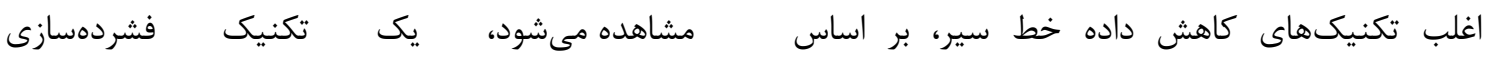

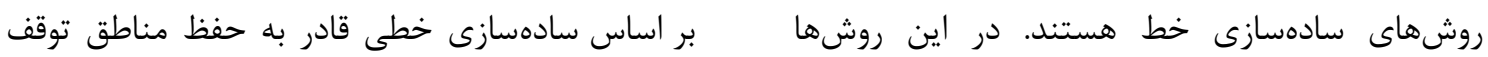

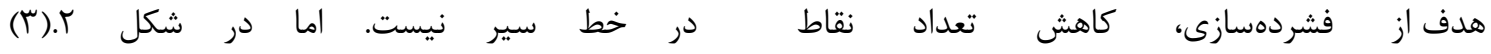

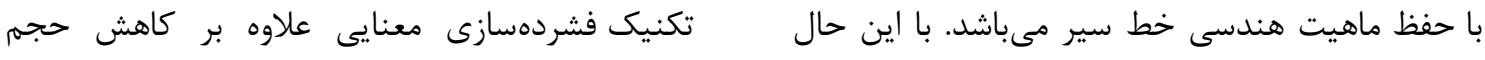

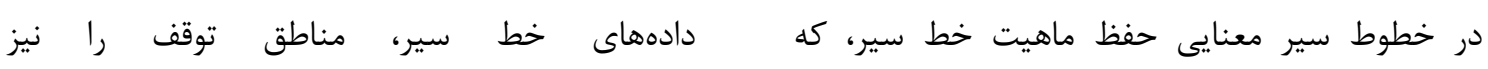
مستلزم حفظ نقاط توقف مىباشد، از اهميت بالايى مفظ كرده است

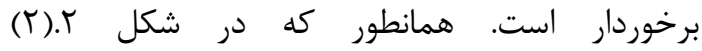

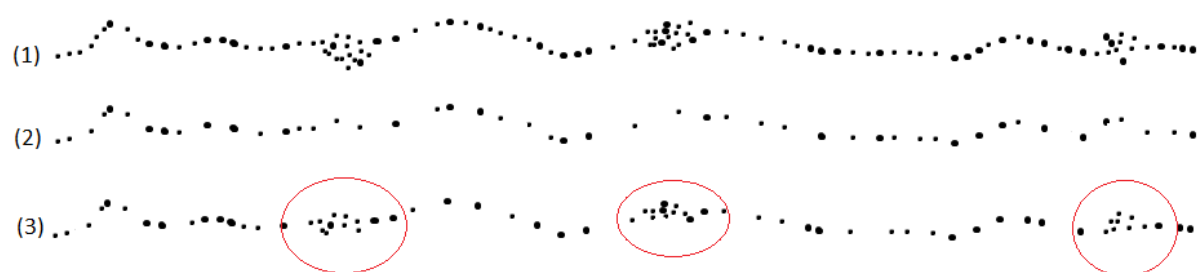

شكل r- ضرورت فشردهسازى خطوط سير براى حفظ مناطق توقف، (1) خط سير اصلى، (r) خط سير فشردهسازىشده با

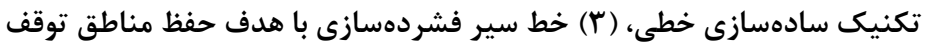

در آناليزهاى مكانى و معنايى مورد استفاده قرار كيرد.

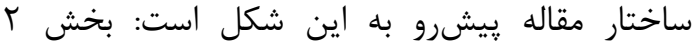

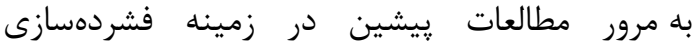

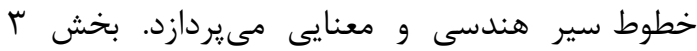
به بيان مبانى نظرى اين تحقيق يرداخته است. در بخش f أروش پيشنههادى معرفى و تحليل شده است و مراحل مختلف روش مورد بررسى قرار ترفتئه است.

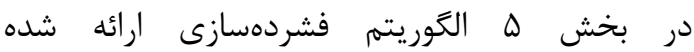
روى دادهاى واقعى بِيادهازى شده و نتايج آن
به علت وجود كاستىهاى مذكور در روشهاى موجود، اين مقاله سعى در ارائه روشى جديد براى رفع دائ دائ

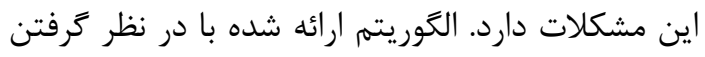
سرعت و زمان حركت شئ متحرك و انجام يردازشهاى

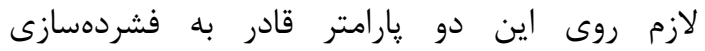
خط سيرهاى مكانى با حفظ مناطق توقف و حركت

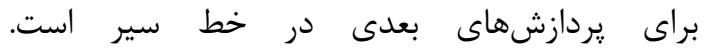
نتيجه اين تحقيق مىتواند به عنوان مسيرى جديد در فشردهازى خطوط سير معنايى براى استفاده 


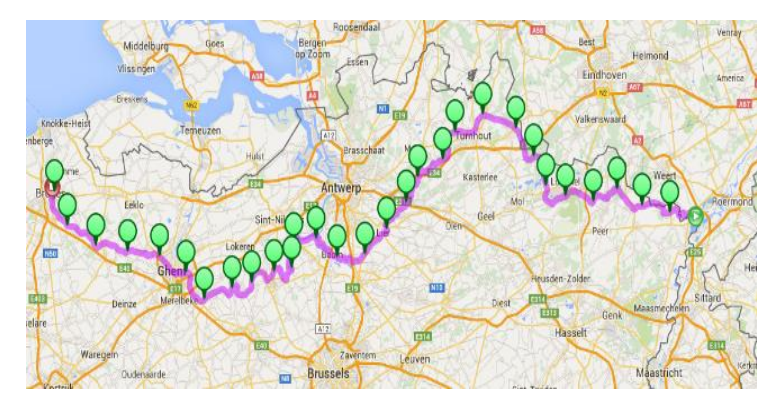

شكل r - نمايى از خط سير هندسى در سايت bikely5

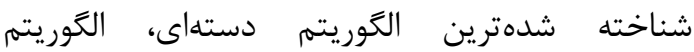

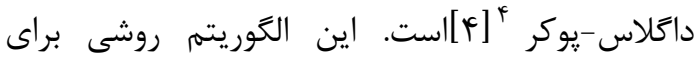
سادهازى خط با كاهش تعداد نقاط است. در اين روش، اندازهخيرى خطا بر اساس فاصله اقليدسى قائم انجام مىشود و از ميانگين و يا مجموع فواصل خطا

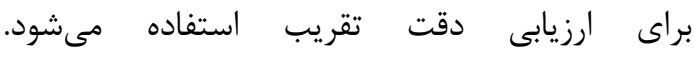
اين روش اندازهزيرى خطا به شدت به به تعداد نقاط نمونه وابسته است. ايده تصوير تمام نقاط ممكن در خط سير اصلى روى ياره خط تقريبى نقاط، كه اساس اين روش است، تنها ويزگى هاى مكانى نقاط خط سير

را در نظر مى گيرد و بعد زمانى ناديده گرفته مىشود. فاصله اقليدسى همزمان، روشى براى اندازهيرى خطى خطا

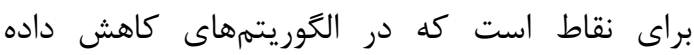
خط سير نيز مىتواند استفاده شود. براى يرداختن

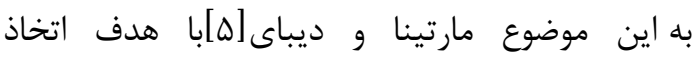
معيارهاى جديد خطا كه نرخ فاصله زمانى هارناميده مىشود، به جاى فاصله اقليدسى قائم از فاصله اقليدسى جدي

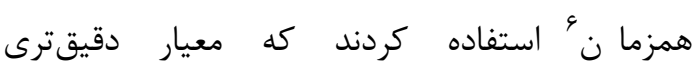

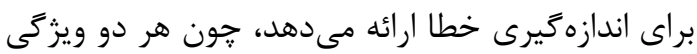

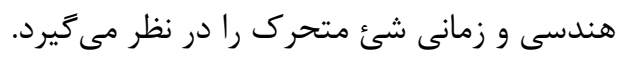

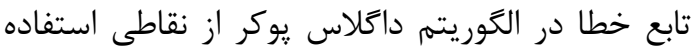

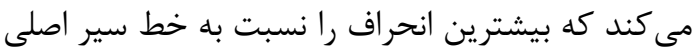
دارد. با اين حال هيج تضمينى وجود ندارد كه اين نقاط بين

\footnotetext{
${ }^{4}$ Douglas-Peucker algorithm

5 Time distance ratio

6 Time synchronized
}

$$
\begin{aligned}
& \text { مورد ارزيابى قرار رقتته است. بخش آخر نيز } \\
& \text { به جمعبندى و نتيجه كيرى مى مورديرازي. } \\
& \text { r- مرورى بر مطالعات ييشين }
\end{aligned}
$$

مطالعات گستردهاى در حوزه فشردهسازى خط سير

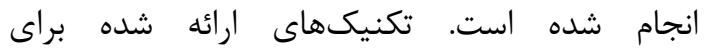
فشردهازى خط سير بر اساس نوع خط سير رال مى توان به دو دسته تقسيم كرد: 1. تكنيكهاى فشردهسازى مبتنى بر خطوط دوس سير

هندسى r. تكنيكهاى فشردهسازى مبتنى بر خطوط سير معنايى در ادامه به بررسى و ارزيابى نمونههايى در هر يك از دستهبندىهاى فوق يرداخته مىشود.

\section{ץ-1- تكنيـــ هــاى فشــر دهســازى مبتنــى بــــ خطوط سير هندسى}

به طور كلى مطالعات مربوط به تكنيكهاى كاهش داده

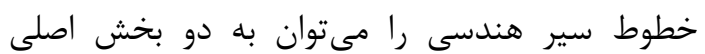
بر اساس نحوه بررسى و ورود دادهها در الگوريتهم تقسيم كرد: فشردهسازى آفلاين و فشردهسازى آنلاين. در تكنيكهاى فشرده سازى آفلاين يا دستهاى 'ابتدا

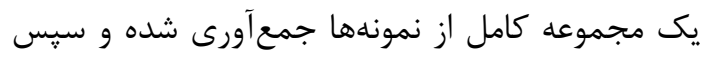
فشردهسازى مجموعه دادها با حذف دادههاى اضافى انجام مىشود. از آنجا كه اين تكنيكهاى فشردهسازى

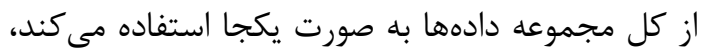
نتايج آنها منجر به دستيابى به دقتى بهتر نسبت به

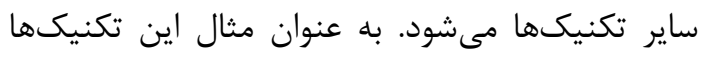

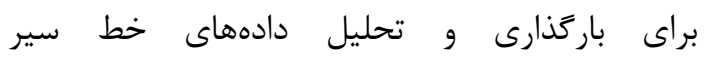

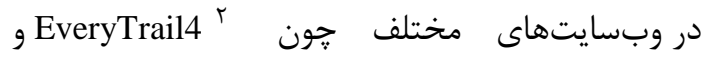
bikely5 ${ }^{r}$ به بررسى نمونهايى از اين تكنيك يرداخته مىشود.

\footnotetext{
${ }^{1}$ batched

${ }^{2} \mathrm{http} / / / \mathrm{www}$.everytrail.com

${ }^{3} \mathrm{http} / / /$ www.bikely.com
} 


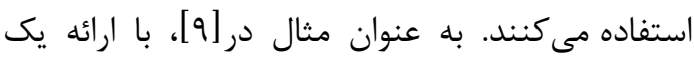

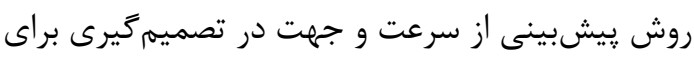
حفظ يا حذف نقاط از مجموعه داده استفاده شده است. در الكوريته يِيشنهادى با تعريف منطقه امن به ارزيابى هر يك از نقاط خط سير يرداخته شده است.
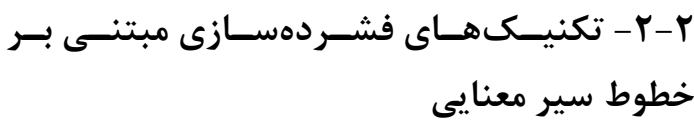

روشهاى كاهش داده خطوط سير معنايى با هدف حفظ مناطق توقف و حركت در مجموعه دادهها

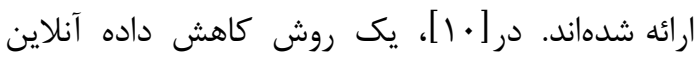
بر اساس حفظ نقاط مههم در خط سير ارائه شده است. اين روش روى دادههاى خط سير كشتى رياده سازى شده است. در روش يِيشنهادى، موقعيت هر كشتى رداري

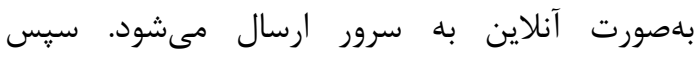
سرعت لحظهاى هر يك از نقاط به طور تقريبى با كمى نقطه قبل محاسبه مىشود. در الكوريته ارائه شده

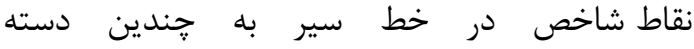
تقسيم مىشوند. سيس با تعريف سرعت هر يك از نقاط و مقايسه سرعت حاصل با حد آستانه تعريف شده براى هر گروه از نقاط شاخص تعريف شده، الكوريته

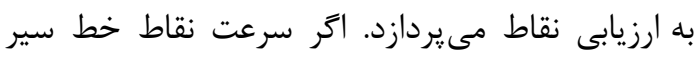

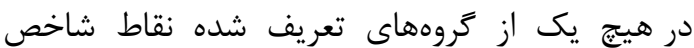
نباشد، نقاط از مجموعه داده حذف مىشوند

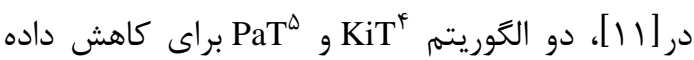
خط سير ارائه شده است. در الكوريتم KiT نقاط مهم به له دسته تقسيم مىشود و نقطهاى كه در اين ه دسته قرار نخيرد از خط سير حذف مى شود. الكوريتم

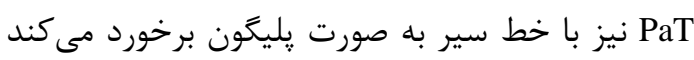

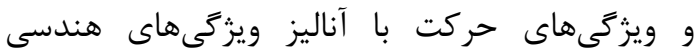

$$
\text { يليكون به دست آيد. }
$$

در روشهاى ارائه شده در [1 |, • [1]

\footnotetext{
4 Key-in-Trajectory

5 Polygon-as-Trajectory
}

بهترين انتخاب باشند. الكوريته بلمن '[ع]از تكنيك نقاط نقاط برنامه نويسى يويا براى تقريب نقاط در فضاى يك التين

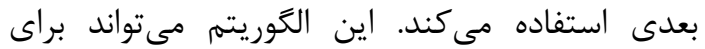
تقريب خط سير در فضاى دو بعدى نيز تعميم

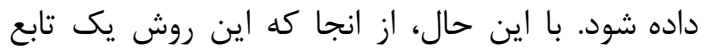

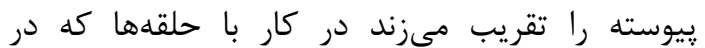

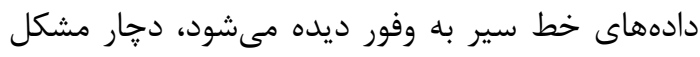

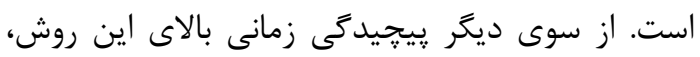
مشكل بعدى اين الكَوريتم است. بسيارى از خدمات مكان مبنا نياز به بروزرسانى آنلاين دادههاى خط سير دارند. به عنوان مثال در مديريت

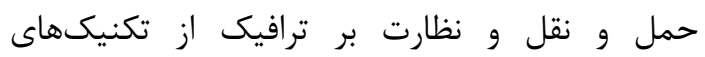

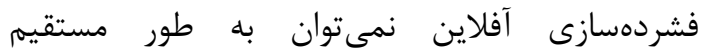

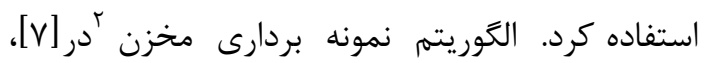

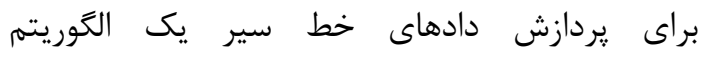
مناسب است. در اين روش موقعيت n نقطه ابتدايى بهاعنوان تقريب خط سير ذخيرهسازى مىشوند. با اضافه شدن هر نقطه در اين رئ روش، الكوريتم

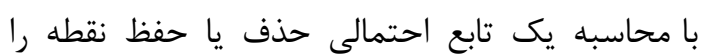
مشخص مى كند.

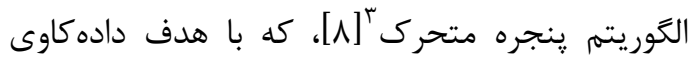

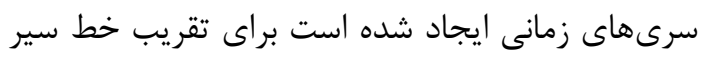

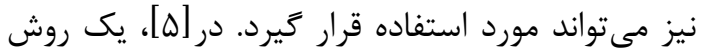
كاهش داده آنلاين بر اساس الكَوريتم ينجره متحرى ارائه شده است. در روش קֶنههادى از هر دو فاصله اقليدسى قائم و اقليدسى همزمان براى كاهش دادي داده خط سير استفاده شده است. علاوه بر تكينكهاى كاهش داده آفلاين وآنلاين كه از إند

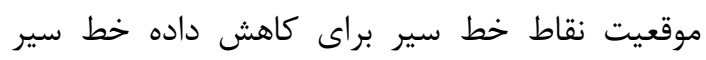

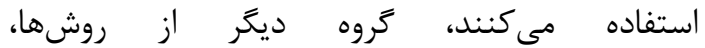

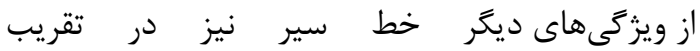

\footnotetext{
1 Bellman

${ }^{2}$ reservoir

3 Sliding window
} 
در مدل PLS استفاده شود. شكل ع أنمونهاى از توابع خطا را نشان مى دهد، كه در ادامه به مرور هر يك ند از توابع يرداخته مىشود.

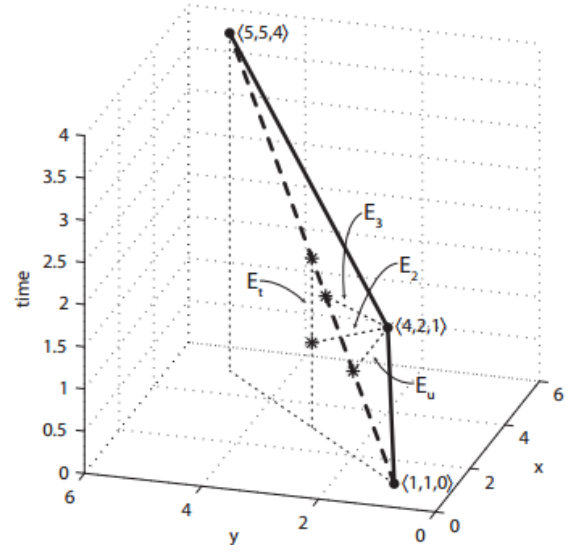

شكل F- روابط بين توابع مختلف فاصله [12]

E2 داكلاس - يوكر است كه در آن خط سير به صورت

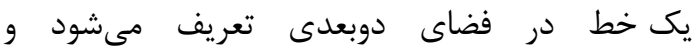
از يارامتر زمان صرفنظر مىشود.

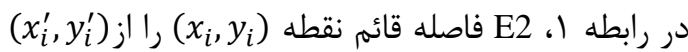
روى ياره خط واصل دو نقطه ابتدا و انتهاى خط سير بعنى

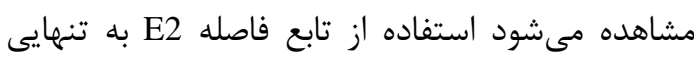
براى فشردهازى خط سير كافى نيست، جون بعد زمان در اين تابع فاصله ناديده كَرفته مىشود. تع

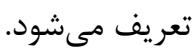

در رابطه r ז، واصل دو نقطه ابتدا و انتهاى خط سيط سير يعنى ( $)$ و $\left(x_{i}, y_{i}, t_{i}\right)$ : در اين تابع خطا، زمان به صورت بعدى است كه بلهصورت متفاوت عمل مى كند و درونيابى خطى آن آن

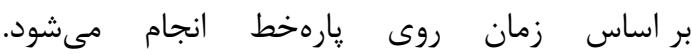
اين تابع فاصله همان فاصله اقليدسى همزمان بان نام دارد.

${ }^{2}$ Synchronized Euclidian distance
در دادههاى خط سير نيازمند معرفى بازه تعيين كننده

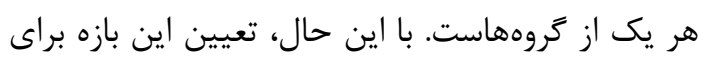
هر يك از گروهها يك خالش است. از سوى ديكر،

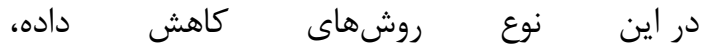
مقادير شناسايى شده در هر گروه به مقادير حد بالا و

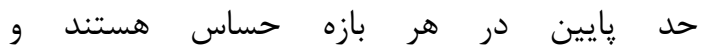
با وجود كوجكترين اختلاف با مقادير مرزى ممكن است بسيارى از نقاط به اشتباه از مجموعه دادهها

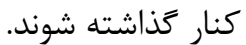
در اين مقاله روش كاهش دادهاى ارائه شده است كه از تلفيق دو تابع در فشردهسازى استفاده مىكند.

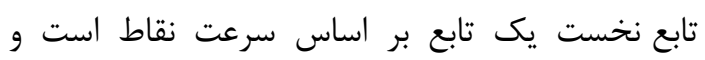
تابع دوم نيز توسعه الكَريتم داكلاس-يوكر است.

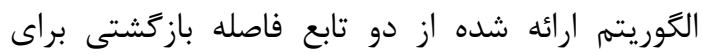

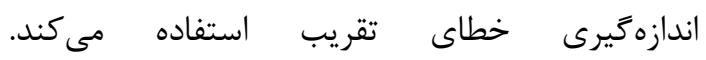
به اين ترتيب روش ارائه شده مشكلات موجود

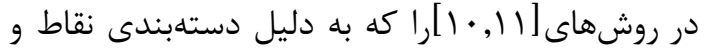
تعيين بازه تعيين كننده نقاط مهم ايجاد شده است،

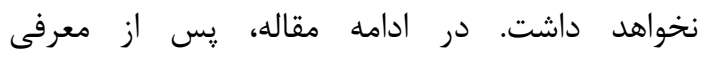
مفاهيم اوليه، روش پيشنهادى ارائه مى گردد.

\section{r- مبانى نظرى تحقيق}

تكنيكهاى فشردهازى استاندارد بر اساس سادهازى خطى براى حفظ نقاط مهم در خط سير

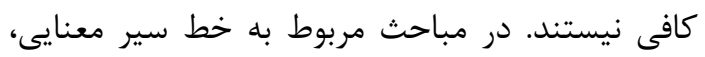

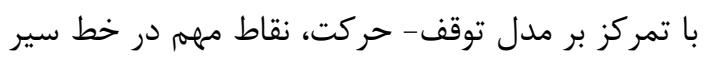
همان مناطق توقف هستند كه در آن شئ متحرك

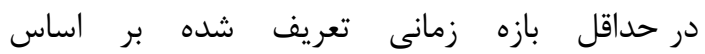
كاربرد موردنظر در آن منطقه باقى بماند. در اين كار

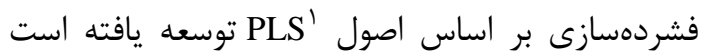
كه در آن براى حفظ مناطق تودف است و و حركت،

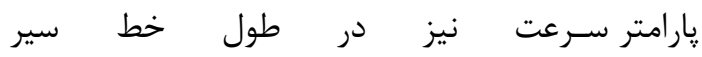
در نظر گرفته مىشود. توابع خطاهاى مختلفى مىتواند

${ }^{1}$ Piecewise Linear Segmentation 


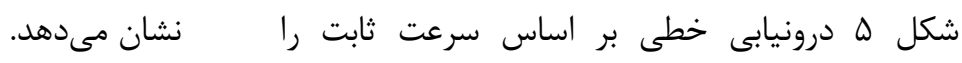

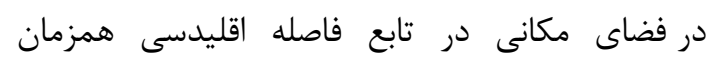

$$
\begin{aligned}
& E_{2}\left(\left(x_{i}, y_{i}\right),\left(x_{1}, y_{1}\right),\left(x_{n}, y_{n}\right)\right)=\left\|\left(x_{i}-x_{i}^{\prime}\right)^{2}+\left(y_{i}-y_{i}^{\prime}\right)^{2}\right\| \\
& \text { رابطه (1) } \\
& E_{3}\left(\left(x_{i}, y_{i}, t_{i}\right),\left(x_{1}, y_{1}, t_{1}\right),\left(x_{n}, y_{n}, t_{n}\right)\right)=\left\|\left(x_{i}-x_{i}^{\prime}\right)^{2}+\left(y_{i}-y_{i}^{\prime}\right)^{2}+\left(t_{i}-t_{i}^{\prime}\right)^{2}\right\| \\
& \text { رابطه (r) } \\
& \operatorname{SED}\left(\left(x_{i}, y_{i}, t_{i}\right),\left(x_{1}, y_{1}, t_{1}\right),\left(x_{n}, y_{n}, t_{n}\right)\right)=\left\|\left(x_{i}-x_{i}^{\prime}\right)^{2}+\left(y_{i}-y_{i}^{\prime}\right)^{2}\right\| \\
& \text { رابطه (r) } \\
& x_{i}^{\prime}=x_{i}+v_{1 n}^{x} \cdot\left(t_{i}-t_{1}\right), \quad y_{i}^{\prime}=y_{i}+v_{1 n}^{y} \cdot\left(t_{i}-t_{1}\right) \\
& \text { (f) رابطه } \\
& v_{1 n}^{x}=\frac{x_{n}-x_{1}}{t_{n}-t_{1}}, \quad v_{1 n}^{y}=\frac{y_{n}-y_{1}}{t_{n}-t_{1}} \\
& \text { رابطه (ه) }
\end{aligned}
$$

به

واضح است كه استفاده از توابع فاصله E

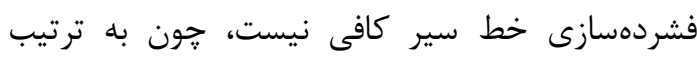
بعد زمانى و مكانى ناديده ترفته مىشود.

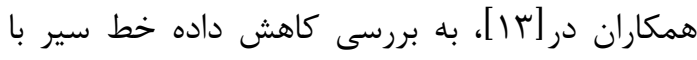

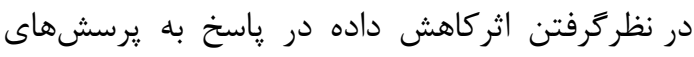

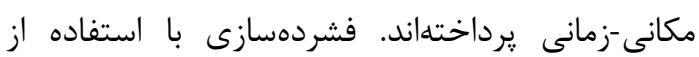

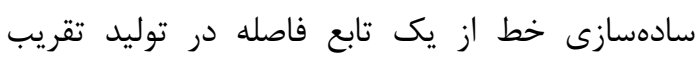
خط سير استفاده مى كند. در اين روش كاهش دادئ فاده،

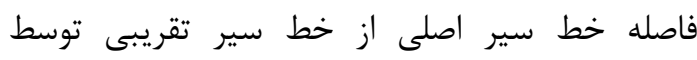

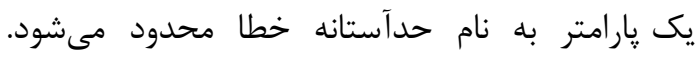

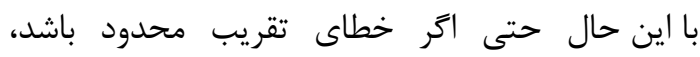

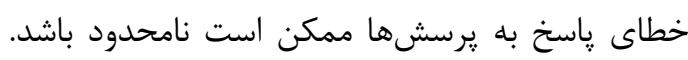
به عبارت ديكر، در جستجو روى خط سيرهاى ساده باه باه

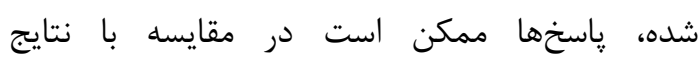
بلهدست آمده از خط سير اصلى، انحراف داشته مانه باشند.

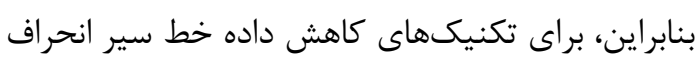

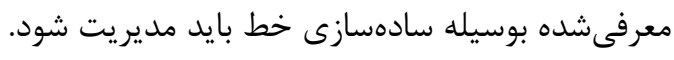

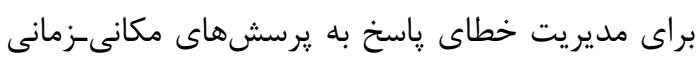

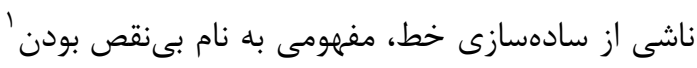

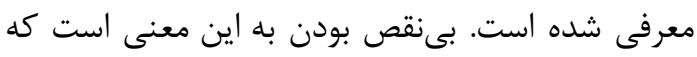

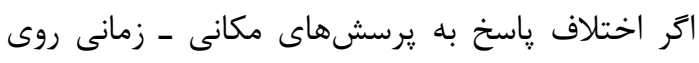

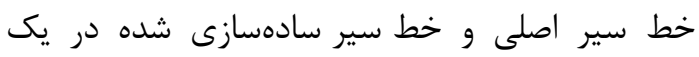

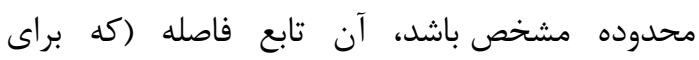

${ }^{1}$ soundness
روابط ץ تا ه محاسبات تابع خطاى اقليدسى همزمان را

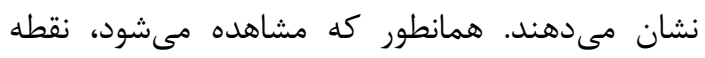
( بارهخط واصل بين ابتدا و انتهاى خط سير يعنى با به اين ترتيب تابع فاصله اقليدسى همزمان از هر دو بعد مكانى و زمانى خط سير در تقريب استفاده مى كند.

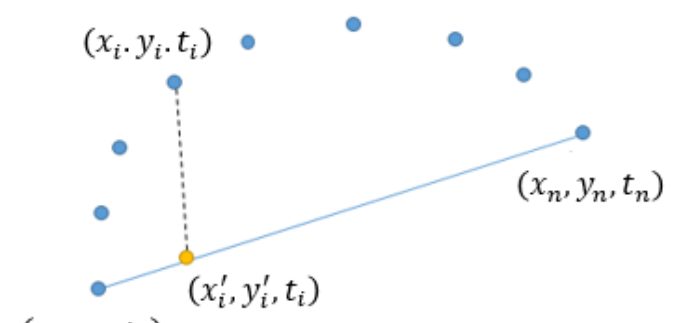

$\left(x_{1}, y_{1}, t_{1}\right)$

شكل ه- درونيابى خطى بر اساس سرعت ثابت در تابع

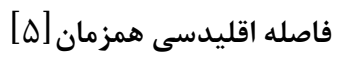

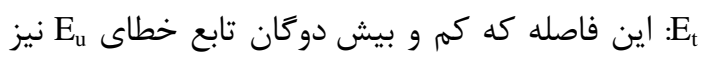

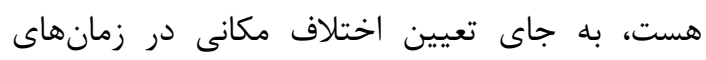
يكسان (تعريف E E

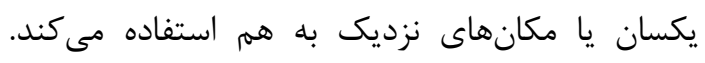

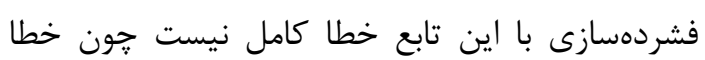
در بعد مكانى ناديده كرفته مىشود. رابطه (ع)

$E_{t}\left(\left(x_{i}, y_{i}, t_{i}\right),\left(x_{1}, y_{1}, t_{1}\right),\left(x_{n}, y_{n}, t_{n}\right)\right)=$ $\sqrt{\left(t_{i}-t_{i}^{\prime}\right)}$

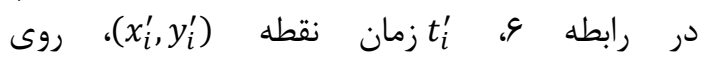
نكاشت دوبعدى ياره خط واصل دو نقطه $)$ روى صفحه xy است كه نزديكترين نقطه 


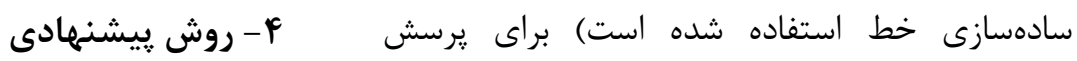
در اين تحقيق تمركز روى حفظ نقاط توقف خط

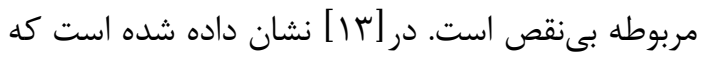
سير معنايى در مسير فشردهسازى دادهها است.

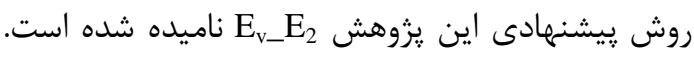

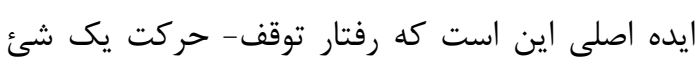

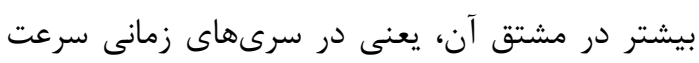

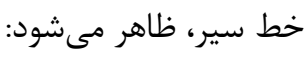

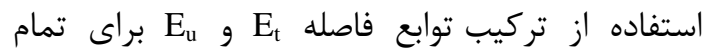

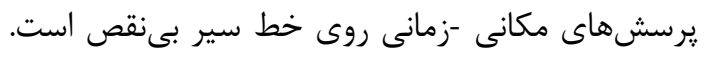

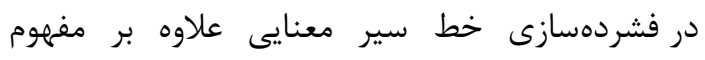

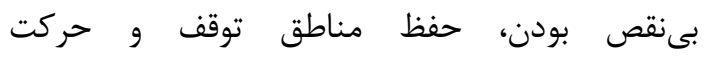
در خط سير نيز مهمم است. بر اساس مطالب بيان شده، روش ييشنهادى در بخش بعد معرفى مىشود.

به اين ترتيب درونيابى خطى نيز با همين فرض نقطه

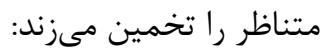

$v_{i}^{\prime}=v_{1}+a_{1 n \cdot} \cdot\left(t_{i}-t_{1}\right)$

رابطه (ᄉ)

$a_{1 n}=\left(v_{n}-v_{1}\right) /\left(t_{n}-t_{1}\right)$

رابطه (9)

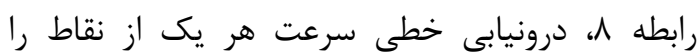

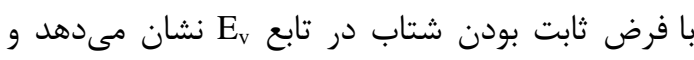

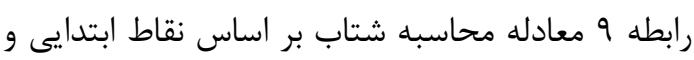

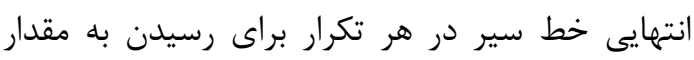

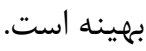
كام دوم در كاهش داده خط سير با استفاده از الكوريتم فاصله E_ E

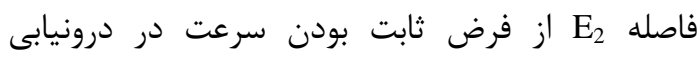
Ev استفاده مى كند. همانطور كه اشاره شد، تابع فاصله از فرض شتاب ثابت استفاده مى كند. بنابراين براى

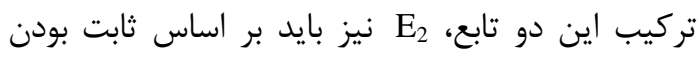

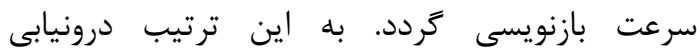

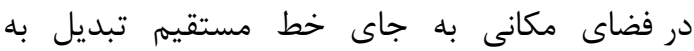

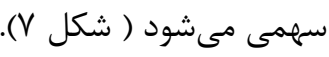

در رابطه V، در اين تابع فاصله،

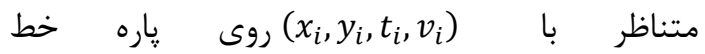
واصل اما فشردهازى صرفاً بر اساس سرعت كامل نيست. در اين كار يك الكوريتم دو مرحلهاى به نام

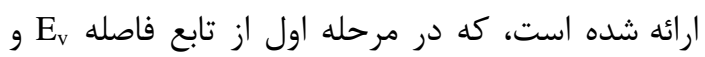

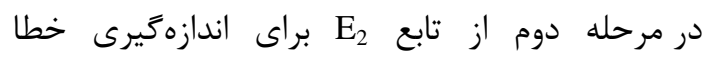
استفاده مى كند. در تابع خطا Es همزمان متناظر با بان

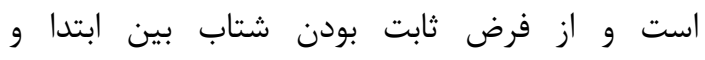
انتهاى خط سير استفاده مىكند. شكل و خطى بر اساس سرعت را در فضاى سرعت -زمان راسير استفادهان

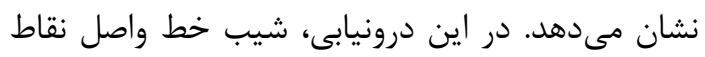

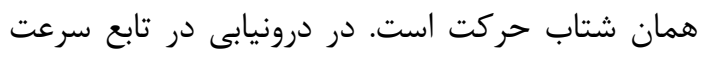
از فرض ثابت بودن شتاب حركت استفاده شده است.

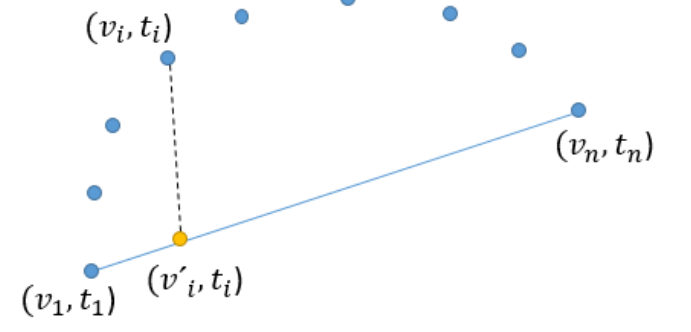

شكل 9- درونيابى خطى تابع فاصله Ev براساس شتاب ثابت 


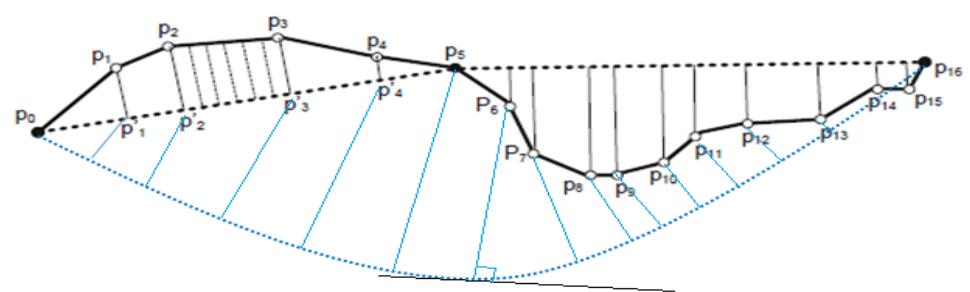

\section{شكل V - تابع فاصله E2، مقايسه درونيابى با سرعت ثابت و شتاب ثابت}

حدآستانه سرعت بر اساس بيشترين فاصله در تقريب

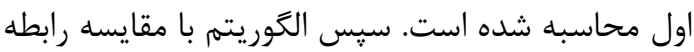
بيشترين فاصله با حد آستانههاى تعيين شده، نقطه مورد نظر را براى تقريب خط سير ارزيابى مى كند. باصن.

\section{ه- ييادهسازى و ارزيابى نتايج}

ييادهسازى تكنيكهاى فشردهسازى روى دادههاى

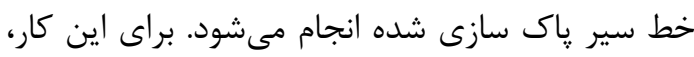
از يك روش سرعت-مبنا براى شناسايى و حذف

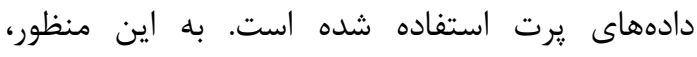
سرعت لحظهاى نقاط به صورت تقريبى با كمك دو دو نقطه قبل و بعد محاسبه شده است. سيس از قانون ب- بـ

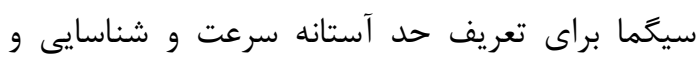
حذف دادههاى يرت استفاده شدهاست. براى קياده سازى، الكوريتم فشرده سازى

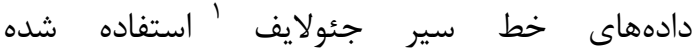

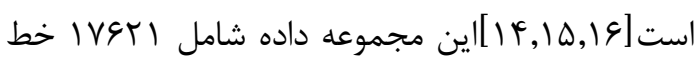

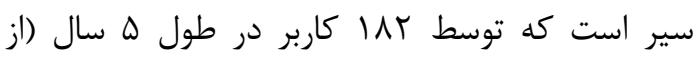

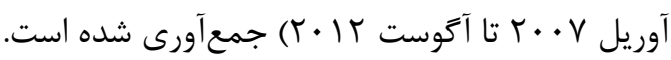
دادهاى جمعآورى شده توسط دستغاههاى مجهز به

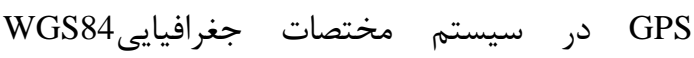
جمع آورى مىشوند. از آنجائيكه در محاسبه تابع فاصله Ev است) خط سير به صورت دنبالهاى از سرعت نقاط نمايش مى يابد، تبديل مختصات از سيستم جغرافيايى به سيستم مختصات كارتزين ضرورى است. بنابراين، ابتدا روى دادههاى مورد نظر تبديل مختصات لازم

\footnotetext{
${ }^{1}$ GeoLife
}

نكته ديخرى كه بايد به آن توجه شود، موضوع هم مقياس نبودن دو تابع فاصله E2 و E E مقادير است. ايده استفاده شده در اين كار براى هم مقياس كردن دو تابع فوق، تقسيم فواصل خطاى

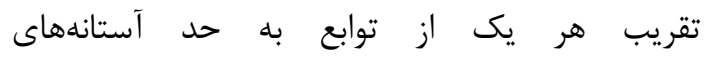
تعريف شده است. $E_{v-} N D=E_{v} / T h_{-} E_{v}$ رابطه ( • (1) $E_{2-} N D=E_{2} / T h_{-} E_{2}$ رابطه (1) در رابطه • (، $E_{v} E_{v-} N D$ مقدار بدون واحد تابع فاصله است و Th_E_ حد آستانه تعريف شده در تابع فاصله E

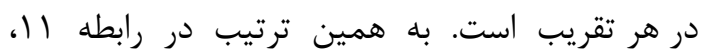

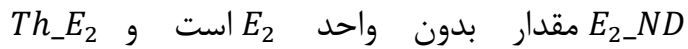
حد آستانه تعريف شده در تابع فاصله $E_{2}$ شناسايى نقطه با بزرگترين فاصله در هر تقريب است.

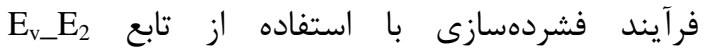

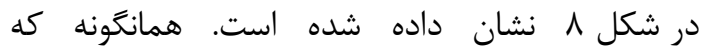
مشاهده مىشود، ابتدا داده هاى خط سير ورودى كه بهصورت ليستى منظم از نقاط به شكل (x,y,t) وارد فر آيند محاسباتى مىشود. سيس فاصله هر يك از نقاط خط سير از اولين تقريب يعنى خط واصل نقاط ابتدا و

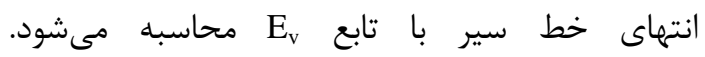
اين محاسبات با فرض استفاده از تابع E2 نيز براى نقاط خط سير انجام مىشود. به اين ترتيب فاصله هريك از نقاط از سهمى ايجاد شده به واسطه ابتدا و انتهاى نقاط، محاسبه مىشود. با محاسبه فاصله نقاط با دو تابع

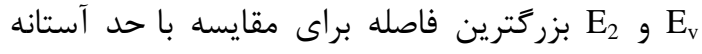

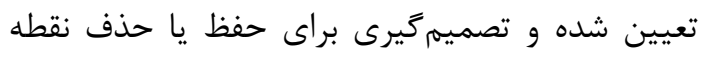
مورد نظر، انجام مىشود. در اين تحقيق تعيين 
الكَوريتمى براى فشردهسازى خطوط سير مكانى .....

سميه عاقل شاهنشين و ديكر همكاران

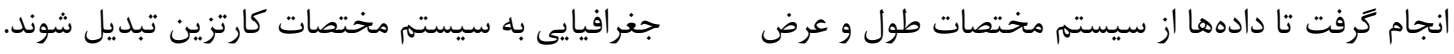

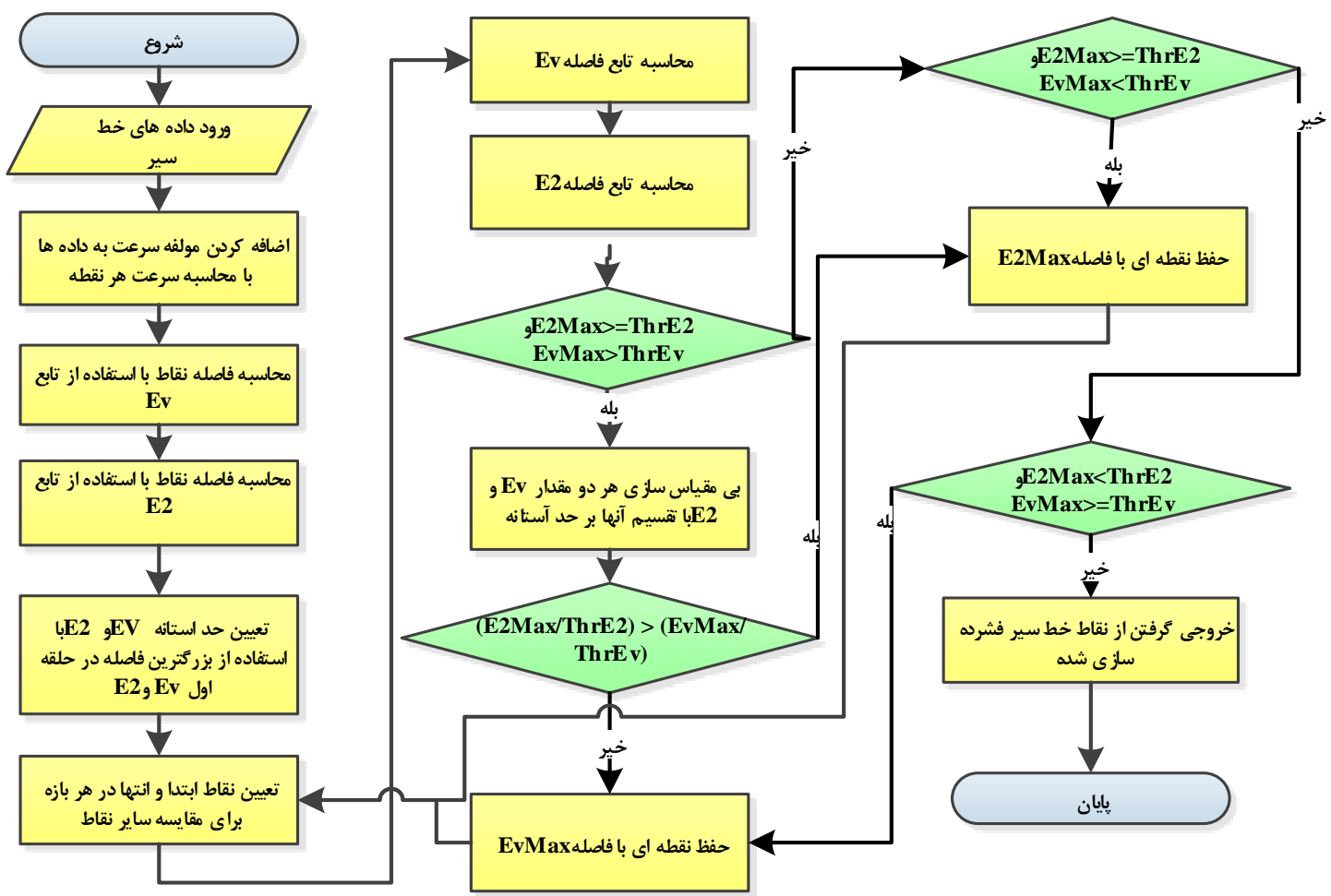

شكل ^- فر آيند فشردهسازى با استفاده از تابع Ev_E2

با الخوريتم داكلاس-يوكر نشان مىدهد. در اين شكل،

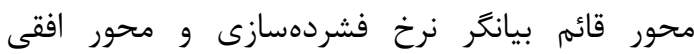

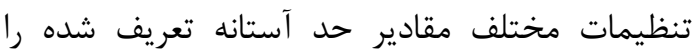
بر اساس بيشترين فاصله نشان مىدهد. همانطور كه Eشاهده مى شود، نرخ فشردهسازى الخوريتم نسبت به الكوريتم داكلاس-هيوكر بيشتر است. با توجه

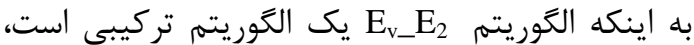
نقاط حفظ شده بيشتر، اغلب نقاطى هستند كه تابع بر اساس فاصله در فضاى سرعت-زمان آنها را بلهعنوان نقاط مهمم شناسايى و حفظ كردهاست. بنابراين حفظ مناطق توقف در خط سير به بهاى افزايش نرخ فشردهسازى است. يارامتر ديخر براى ارزيابى دقت يك

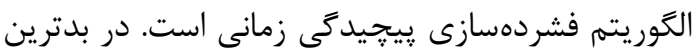

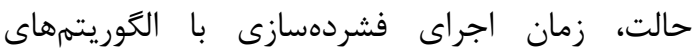
ساده سازى خطى استاندارد (به عنوان مثال الكوريتم

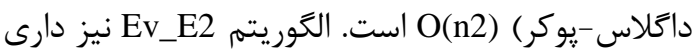

با ياكسازى دادهها از خطا و انجام تبديلات لازم روى

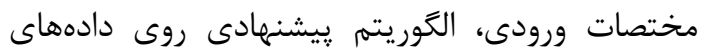
خط سير پيادهسازى شد. نتايج به دست آمده حاكى از موفقيت الكوريتم در كاهش تعداد نقاط، همزمان با بـان بـان حفظ مناطق توقف در خط سير است. ارزيابى الكوريتمهاى فشردهسازى بر اساس پارامترهاى مختلف مىتواند انجام شود. يكى از معيارهاى ارزيابى، نرخ فشردهسازى است. نرخ فشردهسازى برابر با نسبت تعداد

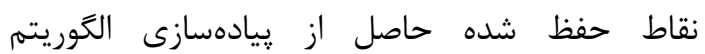
فشردهسازى به تعداد كل نقاط در خط سير است.

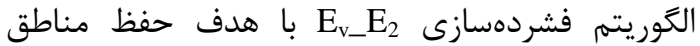
توقف در خط سير اجرا و ييادهسازى شده است.

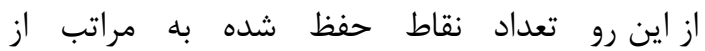
الخوريتمهاى فشردهسازى معمولى كه بر بر اساس سادهازى خطى هستند بيشتر است. شكل 9

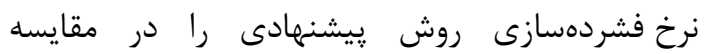


مورد توجه محققان اين حوزه بوده است. در فرآيند غنى سازى معنايى خط سيرهاى مكانى يك گام مهرم در در مديريت داده ها، كاهش تعداد نقاط با حفظ دقي دمان موردنياز براى آناليزهاى مختلف است. با اين هاهئ حال اغلب تكنيكهاى كاهش داده بر اساس ماهيت مكانى زمانى خط سير هستند و تمركز روشهاى ارائه شده كه اغلب ماده بر اساس سادهسازى خطى هستند، حفظ نقاطى از هـ خط سير است كه قادر به نمايش انحراف شئ متحرى

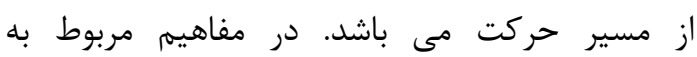

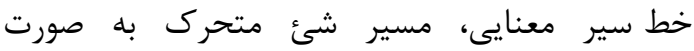

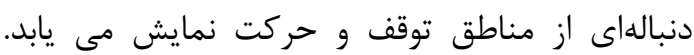
با اين حال اغلب تكنيكهاى كاهش داده خطاه خط سير قادر به حفظ مناطق و توقف نيستند. در اين مقاله يك روش كاهش داده خط سير بر اساس سرعت نقاط ييشنهاد شده است كه در آن تابع فاصله خط سير مكانى -زمانى را به شكل يك سرى زمانى از سرعت نقاط در نظر مى گيرد. روش پيشنهادى كه از تركيب دو تابع فاصله E استفاده كرده است، هدف حفظ نقاطى از خط سير است كه در فضاى سرعت زمان بيشترين انحراف را از

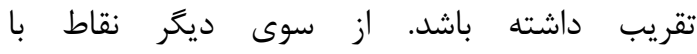
بيشترين انحراف در فضاى مكانى-زمانى نيز به عنوان نقاط مهرم در خط سير حفظ مىشوند.

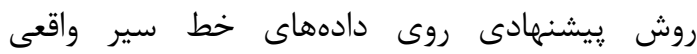

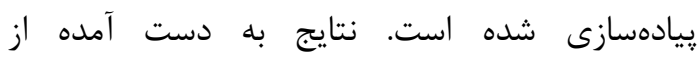

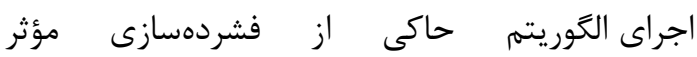
دادههاى حركت با حفظ مناطق و توقف در خط سير است. با اين حال اين امر منجر به افزايش نرخ

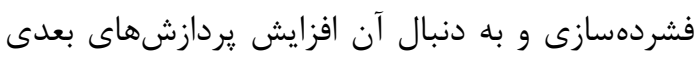
روى دادههاى خط سير است. در فرآيند فشردهسازى برى برى خط سير، نقاط با بيشينه و كمينه سرعت در فضاى فري

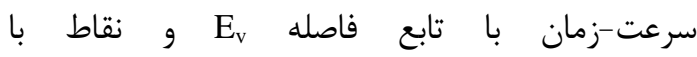
بيشترين انحراف در فضاى مكانى با تابع فاصله در خط سير به عنوان نقاط مهرم حفظ مىشوند و از نقاط ديخر صرف نظر مىشود.
همين ڤييجيدگى است. در واقع، اساساً الكوريتهم Ev_E2 دو بار از الكوريتمهاى PLS استفاده كرده است.

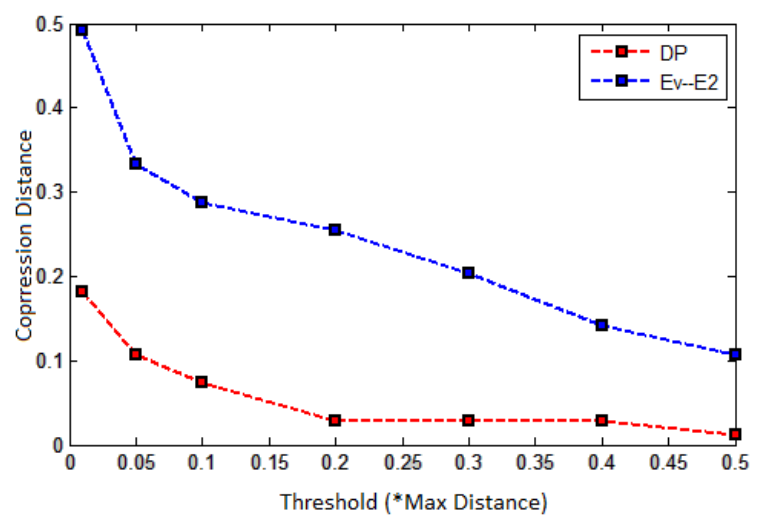

شكل 9- مقايسه نرخ فشردهازى روش داكلاس - هيوكر (خط جين

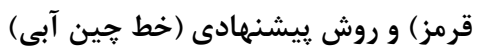

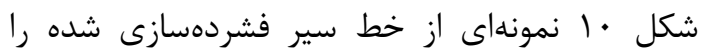

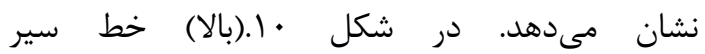

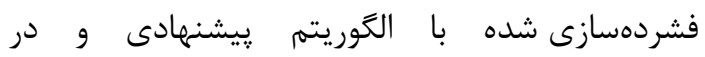
شكل •(إياين) خط سير فشرده شده با الكوريتم داعلاس-يوكر نشان داده شده است. در اين شكل نقاط

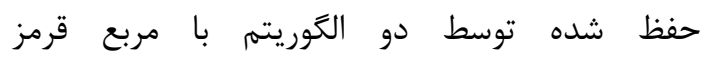

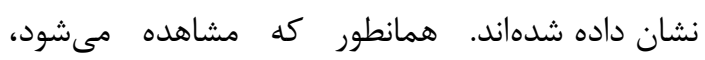
مناطق توقف در خط سير كه اغلب به صورت تراكم

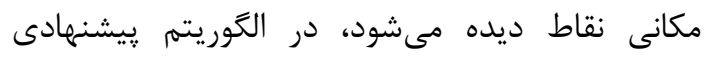

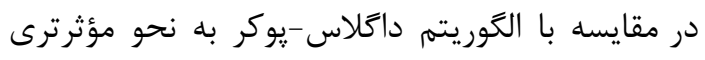
حفظ شده است. اين نقاط مناطقى از خط سير هستند

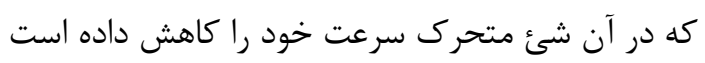
(شكل • (.(وسط)). علاوه بر حفظ نقاط با سرعت پايين

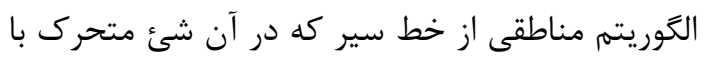
سرعت بيشتر از ميانگين حركت كرده است را حفظ كرده كه علت آن فاصله بيشتر اين نقاط از تقريب خط سير است.

\section{9-جمعبندى و نتيجه گيرى}

با توليد روزافزون دادههاى حركت توسط دستخاههاى تعيين موقعيت، حجم عظيمى از دادههاى مكانى زمانى خط سير توليد شده است. در مطالعات مربوط به خط سير مفهوم خط سير معنايى در خند سال اخير 
الكَوريتمى براى فشردهسازى خطوط سير مكانى ....

سميه عاقل شاهنشين و ديكر همكاران
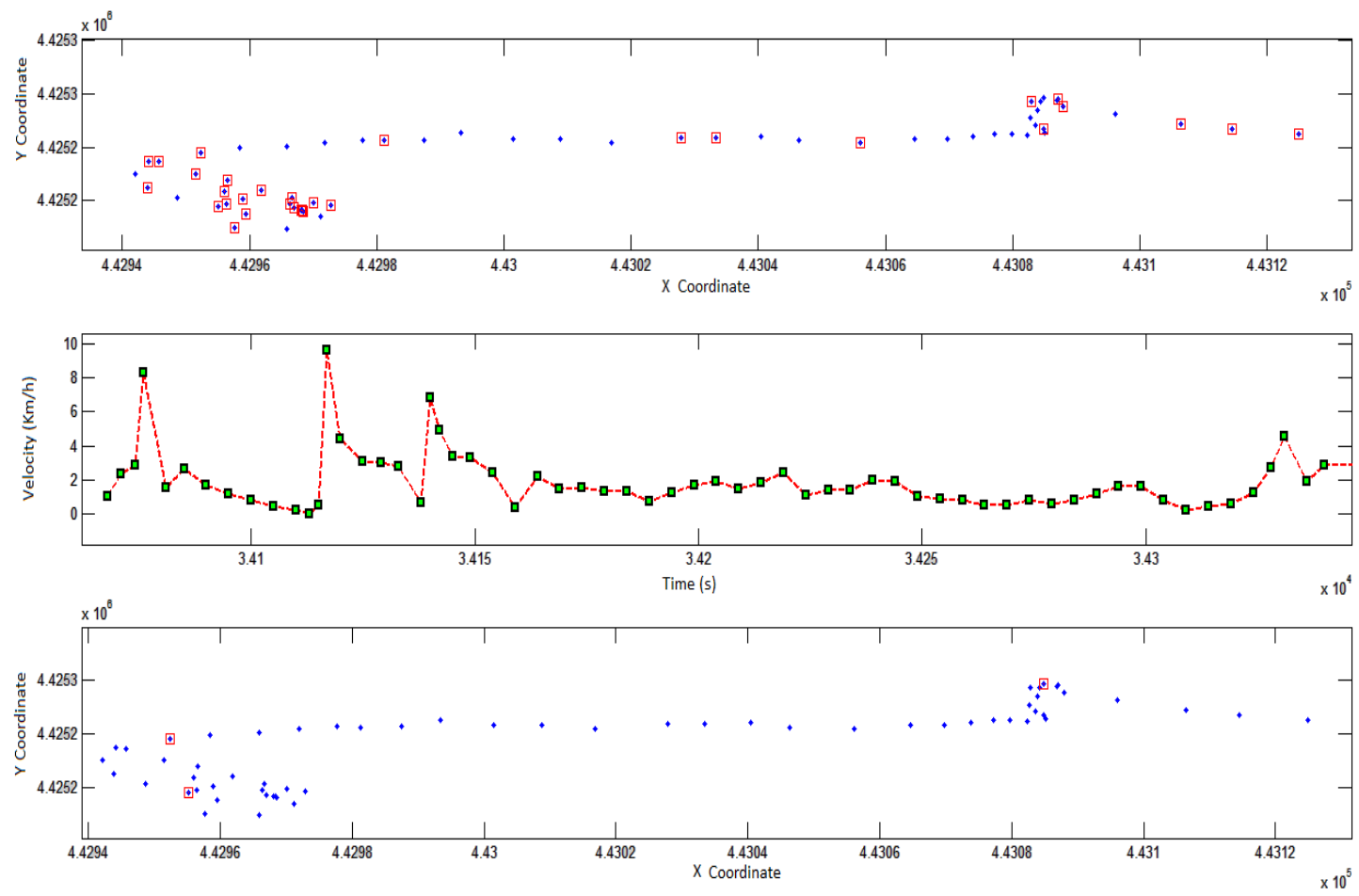

شكل•1- مقايسه نتايج الكَوريته بيشنهادى (بالا)، نمودار سرعت نقاط (وسط) و نتايج حاصل از الكَوريتم داكَلاس يوكر (پايين)

سير انجام مىشود. به اين ترتيب نتايج حاصل از اين

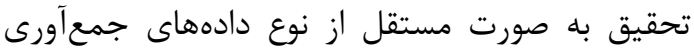

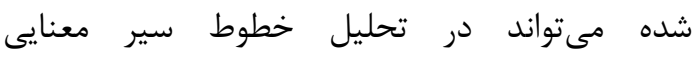

$$
\text { مورداستفاده قرار كيرد. }
$$

[1] Alvares, L. O., Oliveira, G., Heuser, C. A., and Bogorny, V., "A Framework for Trajectory Data Preprocessing for Data Mining," in Conf. on Software Engineering and Knowledge Engineering, 2009.

[2] Pelekis, N., Theodoridis, Y., Janssens, D., "On the Management and Analysis of Our LifeSteps," ACM SIGKDD Explorations Newsletter, vol. 15, no. 1, pp. 23-32, 2013.

[3] Zheng, Y., , Zhou, X., Computing with Spatial Trajectories, New York: SpringerVerlag New York, 2011.

[4] Douglas, D., Peucker, T., "Algorithms for
الكوريتمهاى فشردهازى با هدف كاهش حجم نقاط با حفظ دقت مورد نياز براى تحليلهاى مختلف روى دادهها اجرا مىشوند. زمانى كه هدف از تحليل دادهناي تهاى

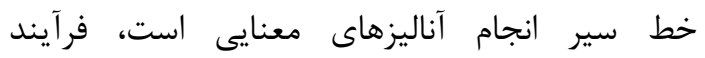
فشردهازى نقاط با رويكرد حفظ مناظق توقف در خط

\section{مراجع}

the Reduction of the Number of Points Required to Represent a Line or its Caricature," Cartographica, vol. 10, no. 2, pp. 112-122, 1973.

[5] Maratnia, N., de By, R., "patio-Temporal Compression Techniques for Moving Point Objects," in International Conference on Extending Database Technology (EDBT), 2004.

[6] R. Bellman, "On the Approximation of Curves by Line Segments Using Dynamic Programming," Communications of the ACM, vol. 4, no. 6, 1961. 
[7] J. Vitter, "Random sampling with a reservoir," ACM Transactions on Mathematical Software(TOMS), vol. 11, no. $1,1985$.

[8] Keogh, E., Chu, S., Hart, D., Pazzani, M., "An On-Line Algorithm for Segmenting Time Series," in International Conference on Data Mining (ICDM), 2001.

[9] Potamias, M., Patroumpas, K., Sellis, T., "ampling Trajectory Streams with SpatioTemporal Criteria," in In: International Conference on Scientific and Statistical Database Management (SSDBM), 2006.

[10]K. Patroumpas, "Online tracking and summarization over streaming maritime trajectories," in Workshop on Moving Objects at Sea, 2013.

[11]W. Ting, "SOMETIMES TOO BIG: COMPRESSING TRAJECTORY DATA," in PACIS 2014 Proceedings, 2014.

[12] de Vries, G. K. D. and ,Someren, M., "Machine learning for vessel trajectories using compression, alignments and domain knowledge," ELSEVIER, vol. 39, no. 18, p. 13426-13439, 2012.

[13]Cao, H., Wolfson, O. and Trajcevski, G., "Spatio-temporal data reduction with deterministic error bounds," The VLDB Journal - The International Journal on Very Large Data Bases, vol. 15, no. 3, pp. 211-228, 2006.

[14]Zheng, Y., Zhang, L., Xie, X., \& Ma, W. Y., "Mining interesting locations and travel sequences from GPS trajectories," in In Proceedings of the 18th international conference on World wide, Madrid Spain, 2009.

[15]Zheng, Y., Li, Q., Chen, Y., Xie, X., \& Ma, W. Y., "Understanding mobility based on GPS data," in In Proceedings of the 10th international conference on Ubiquitous computing, Seoul, Korea, 2008.

[16]Zheng, Y., Xie, X., \& Ma, W. Y., "GeoLife:
A Collaborative Social Networking Service among User, location and trajectory," in IEEE Data Engineering Bulletin, 2010. 


\title{
An algorithm for compression of a spatio-temporal trajectory preserving its semantic nature
}

\author{
Somaie Aghel Shahneshin ${ }^{1}$, Simin Sadat Mirvahabi ${ }^{1}$, Rahim Ali Abbaspor ${ }^{* 2}$ \\ 1- MSc student, School of Surveying and Geospatial Information Engineering, College of Engineering, University of Tehran \\ 2- Assistant professor, School of Surveying and Geospatial Information Engineering, College of Engineering, University of Tehran
}

\begin{abstract}
A common way to store information of spatio-temporal moving objects is to display the path of the objects as the form of a three-dimensional trajectory using the geographic location and time. In recent years, extensive research has been done on the trajectories. These studies have focused mainly on geometric aspects of trajectories. However, semantic trajectory is a relatively new concept that has been developed with the purpose of effective semantic analysis on captured data. In semantic trajectory, which is a secondary display of geometric trajectory, the movement of object is described as series of stop-and-move. Production of semantic trajectory from the collected raw data is a process with several steps. Due to the huge amount of data, one of the important processes is reducing the number of points of trajectory with maintaining the required accuracy by using compression techniques. However, data reduction techniques commonly are based on linear simplification and are not able to protect stop and move of trajectories. In this paper, a data reduction technique is presented which is based on combination of two distance functions for approximation of semantic trajectory. The first distance function has used speed of points to calculate the approximation error of trajectories. The second function is based on the development of well-known Douglas-Peuker algorithm, which assumes constant acceleration to calculate the approximation error. The proposed algorithm is implemented on real trajectory data and the results show improved performance compared with other algorithms in preservation of the stop and move of trajectories.
\end{abstract}

Key words: Semantic Trajectory, compression, Stop-Move Model, $\mathrm{E}_{\mathrm{v}}-\mathrm{E}_{2}$

Correspondence Address GIS Group, School of Surveying and Geospatial Information Engineering, College of Engineering, University of Tehran, Tehran, Iran. Tel: +982188008841.

Email: abaspour@ut.ac.ir 